Adem Ahmed', Senior Lecturer

Department of Mathematics

Bahir Dar University, Ethiopia

Solomon Melesse', Ph. D.

Bahir Dar University, Ethiopia

Tadele Wondimuneh ${ }^{3}, \mathrm{Ph}$. D.

Bahir Dar University, Ethiopia
Original scientific paper

UDC: 371.311 .4

DOI: $10.5937 /$ istrped2001001A

\title{
STUDENTS' PERCEPTION OF THE APPLICATION OF COOPERATIVE PROBLEM- SOLVING METHOD AND ITS EFFECT ON MATHEMATICS PERFORMANCE: THE CASE OF SECONDARY SCHOOLS IN AWI-ZONE, ETHIOPIA
}

\begin{abstract}
This study focuses on high school students' perceptions of cooperative problem-solving learning in mathematics classrooms. Case study was chosen as a research design in this study. Participants of this study were grade 11 students of Dangila preparatory high school in Awi-zone, Ethiopia. The number of participants was 105. The data were collected using Structured Likert scale questionnaire consisting of 15 (fifteen) questions that focus on cooperative problem-solving learning and an unstructured interview. The quantitative data were analyzed using one sample t-test whereas the qualitative one was analyzed using narration on the basis of themes created as per the basic questions of this research. The results of this research showed that students had positive responses toward the implementation of cooperative problem-solving learning. The quantitative data revealed that cooperative problemsolving learning has great effect on students' learning and consequently on their mathematics performance. The qualitative data disclosed the generics skills of students and helped teachers to understand students' perceptions of their experience gained from the learning activities. Besides, it was found that students were familiar with group activities in mathematics classroom. To sum up, cooperative problemsolving learning is a good approach for the students to learn mathematics easily and perform better than before. On the basis of the findings, the researchers have forwarded relevant recommendations.
\end{abstract}

Keywords: Cooperative-learning, Perception, Problem-solving, Students' performance.

\section{Background of the Study}

A high-quality mathematics education provides a foundation for understanding the world, the ability to reason mathematically, an admiration of the beauty and power of mathematics and a sense of enjoyment and wonder about the subject.

Many theorists and researchers (Kamii, 1990; NCTM, 1989; Yackel, Cobb, Wood, Wheatley, \& Merkel, 1990) believe that mathematical knowledge cannot be transmitted, but that students have to actively construct it. One of the means in which mathematical knowledge can be constructed is to engage students in problem solving (Davidson, 1990; Kamii, 1990) and in social interaction (Balacheff, 1990; Cobb, 1991; von Glasersfeld, 1984; Johnson \& Johnson, 
1989; NCTM, 1989; Piaget, 1947;). Research by mathematics educators suggest that students retain best the mathematics that they learn by the process of internal construction and experience (Slavin, 1987). According to Duncker (1945), a problem originates when a living creature has a goal but does not know how this goal is to be reached. Whenever one cannot go from a given situation to the desired situation simply by action, then there has to be recourse to thinking. Such thinking has the task of devising some action, which may mediate between the existing and desired situations. According to Mayer and Wittrock (2006, p. 287), problem solving is "cognitive processing directed at achieving a goal when no solution method is obvious to the problem solver".

There was a significant difference between the effectiveness of the traditional teaching method and problem-solving method in teaching of mathematics at the elementary level (Ali et.al, 2010). According to Pervin (2010), the experimental group of secondary school students using problem solving outscored in mathematics than the control group significantly on the post-test. The achievement level of students taught through the problem-solving approach was significantly different as compared to the performance of the students taught through traditional methods of teaching on the posttest (Behlol, 2018). Better performance of the experimental group was inferred due to active participation, self-directed learning, and higher confidence of the students in the learning process. It was found that students of secondary school taught through problem solving had a better achievement than those taught through the conventional methods (Mwelese \& Wanjala, 2014). A further feature is that a problemsolving approach can be used to encourage students to make inductive reasoning about rules and concepts, a cognitive process which is fundamental to mathematics (Evan \& Lappin, 1994). Several studies have pointed out that teachers' beliefs about the importance and the skills of implementing problem solving teaching approaches have significant effect on students' achievement and problem solving behaviour (Polya, 1995).

On the other hand, cooperative learning is a teaching strategy that encourages students to assist each other in a small group to achieve a common goal (Chan \& Idris, 2017). Through cooperative learning methods, each student in the group is responsible to share opinion and work together to solve the mathematical problem. Slavin (1989-1990) deals with the appropriateness of cooperative learning for higher-order conceptual learning. Patrick and Ochuko (2010) argued that there is a significant higher achievement test score of students in the cooperative learning group than those in the traditional classroom. According to Effandi and Zanaton (2009), the usage of cooperative learning over the traditional method is stressed. Cooperative versus individualistic goal-structured junior secondary school mathematics classrooms in Nigeria improves academic performance (Awofala, Fatade \& OlaOluwa, 2012).

Moreover, problem solving and cooperative communication is among the central 21st century skills educators need students to acquire (Shelly, Wismath \& Doug,2015).The problem-solving method and cooperative learning used with the treatment group is more effective in promoting success in high school graduates in mathematics (Norwood, 1995). Cavanagh (2011) proposes that cooperative learning method can be utilized in problem-solving teaching during the teacher training. Gilbert-Macmillan (1983) expressed that cooperative learning method furnished students with the chance of thinking aloud, created opportunities to meet with different ideas and focused on the problem-solving process more than the solution of the problem. The prospective teachers showed positive effects of working on non-routine problems in a cooperative learning group (Artut, 2016). 


\section{Statement of the Problem}

To build mathematical knowledge, various researchers (Carpenter, 1990) propose that learners become engaged in the solution of more than one-step, non-routine problems. Other researchers (Johnson \& Johnson, 1989) give attention to the social aspect of knowledge construction and advocate the use of cooperative learning. Some researchers (Peterson \& Fennema, 1985) propose that the use of cooperative learning can assist females improve their performance in mathematics. Later, researchers (Driver, Asoko, Leach, Mortimer, \& Scott, 1994) have advised the combination of both approaches.

Driver et. al (1994) indicate that engaging socially in a cooperative circumstance while solving non-routine problems is an excellent way of constructing knowledge. In spite of suggestions to combine both approaches, most cooperative learning studies have focused more on instruction in computing than on problem solving (Leighton, Slavin \& Davidson, 1989). For instance, some research show that cooperative learning is consistently more effective than traditional instruction in accelerating achievement in mathematics computation (Slavin, Leavey, \& Madden, 1984), however, it does not turn to non-routine problem solving.

However, little research is done about how interaction nurtured in cooperative learning settings influences the construction of mathematical knowledge (Balacheff, 1990). Schoenfeld (1987), for instance, points that the interaction that takes place in small group problem solving influences the growth of self-regulation and beliefs (about mathematics and about one's ability to do mathematics), and that these beliefs, in turn, impact students' attitudes and confidence in their ability to do mathematics. Yet, little research exists on the way that self-regulation and beliefs affect knowledge construction in a non-routine problem solving context (Leticia, 1997).

Therefore, the problems to be addressed in this research are investigation of the effectiveness of cooperative problem-solving on: (1) the change in students' perceptions, and (2) mathematics performance scores.

High quality Science, Technology, Engineering and Mathematics (STEM) education has a vital role to play in contributing to society's sustainable development through research and development, innovation, productivity and competitiveness.

Moreover, the descent of students' performance in Mathematics is one of the matters that are being talked about widely. Declining achievement in the subject has evoked great concern among mathematics educators in Ethiopia. In Ethiopia, innumerable efforts have been witnessed for many decades in trying to improve the performance of science subjects in general and mathematics in particular.

For instance, the Ethiopian Ministry of Education (MoE) and Japan International Cooperation (JICA) carried out a three year project entitled 'Strengthening Mathematics and Science Education in Ethiopia' (SMASEE) between 2011 and 2014 to improve mathematics and science lessons for Grades7 and 8 through In-Service Teacher Training (INSET). SMASEE successfully established an effective INSET system and trained 2,300 teachers in different regions (Alazar Shiferaw, 2017). 
Mathematics and Science Improvement Center (MSIC) Director at MoE, said that Ethiopia is making efforts requiring attention in the field of education (Alazar, 2017). Educational and Training policy was formulated and is being carried out. In addition, Quality Assurance Package was planned and put into exercise. Access, equity and quality of education have shown steady progress as a consequence. Thus, for a better quality improvement in the subjects, the Ethiopian government has taken the initiative to work with the Japanese government on the issue.

However, the quality of education needed additional enhancement efforts because the performance of students in mathematics and science subjects had not however reached the required standards. This was partly because teachers still employed teacher-centered teaching methods and students were not active participants in the classrooms.

Despite all these attempts, however, there is a lot to do to improve the quality of education at the classroom level. The knowledge of learning styles and strategies is essential for educating or for developing the potential of children in different ways according to learners' abilities, learning characteristics and needs (Chan, 2001). These projects and several curriculum reviews across many subjects offered at secondary school level have not been able to bring about a remarkable change in students' performance in science subjects in general and mathematics in particular. Different scholars suggest that students' mathematics performances at any level are still worsening from time to time. Different national assessment results can be considered as a witness in the Ethiopian context. For example, the four National Learning Assessment reports of grade eight students mathematics performance in the Amhara region as suggested in the graph (Figure 1.1) disclosed that, it is not only very far below from the expected mean fixed nationally by the Ministry of Education for advancement, which is $50 \%$, but also goes down from time to time (National Educational Assessment and Examination Agency, NEAEA, 1996-2004).There are similar dissatisfactions in almost all regions of the country.

Furthermore, according to Amhara Education Bureau, in 2016 only approximately 33\% of students who took grade 10 national exam in the region have got the passing mark. Mathematics is one of the subjects which many students fail. According to Hailu and Habtamu (2016), Instructional Factors and Individual Factors are the causing factors that attribute to students' low mathematics achievement in grade 10 and about $35.5 \%$ of students scored below grade $\mathrm{C}$.

Thus, this and some other similar problems initiated the researchers to study effects of problem solving and cooperative learning approaches on high school students' perceptions and mathematics performance in secondary schools in Awi zone, Amhara Region, Ethiopia.

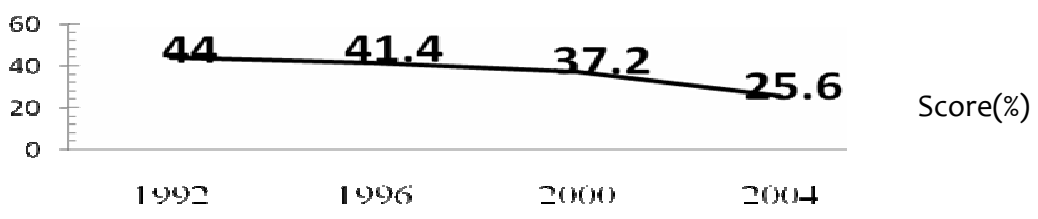

Fig. 1 
To the researchers' best knowledge, no adequate research has been done on the interactive effects of cooperative problem-solving approach worldwide. Furthermore, no research has been done on cooperative problem-solving approach and students' performance in the Ethiopian context.

Even though Ethiopian universities have good Perceptions on practices of problem-solving strategies (Solomon, 2015), high school teachers in Awi-zone, however, do not (Alemayehu, 2010). Therefore, there should be a bridge to narrow this gap.

The researchers have observed that many teachers in high school are not practicing cooperative problem-solving approach classroom, as it has been seen as part of classroom observation.

Therefore, it becomes necessary to conduct the investigation of the preferred learning styles and strategies of secondary school students when they learn mathematics.

As a result, they can improve mathematical problem-solving skills and consequently mathematics achievement. Thus, students can build their conceptualization process. Furthermore, they can get the opportunity to have deep learning by creating relational understanding (relating the topic to other areas in mathematics or diagrams) rather than instrumental understanding (memorizing different methods to answer questions). As a result of this, students' mathematics performance would be improved. Moreover, the quality of school mathematics education will be amended.

Hence, this study is conducted to look into the perception of students on the cooperative problem-solving approach and consequently on their performance. This triggered the researchers to conduct an investigation in the field.

The current study is directed at analyzing the extent to which the issue of cooperative problem-solving approach is effective in learning and mathematics performance.

To substantiate the intention of this research, the following research question was formulated.

- How far the students' perceptions of cooperative problem-solving approach are effective in their learning and performance?

The researchers hope that the findings of this study will help students to:

- Develop a positive attitude and perception towards mathematics

- initiate and develop love for mathematics

- improve their achievement in mathematics

- learn the "History of Mathematics" by sharing its slow and painful development from ancient time to the present

- provide opportunity of communicating and listening to teachers, experts, and arrange mathematical shows and exhibitions.

- get the opportunities of mathematics hobbies, recreational mathematics, mathematical projects, mathematical games, mathematics discussions, debates and mathematical innovations. 
The study is delimited to look into students' perceptions of cooperative problem-solving approach and if it is effective in their learning and performance. Moreover, for the purpose of feasibility, and to make the work realizable, the researchers have determined to delimit their area of study geographically to one zone.

The objectives of the study are to look into and elucidate the students' perceptions towards cooperation problem-solving learning carried out in high school mathematics.

\section{Operational Definition}

Problem solving approach: Engaging in a mathematics task for which the solution method is not known for the time being (in advance).

Cooperative learning: is a teaching method that uses small, heterogeneous ability groups to maximize the learning of each of those group members.

Problem solving skills: Analytical or logical thinking in mathematics such as ordering, comparing, contrasting, evaluating and selecting in problem solving approach.

Mathematics performance: means that a student meets the criteria of the standards to a level which demonstrates adequate understanding of the mathematics concepts of some standardized tests based non-routine problems through cooperative learning.

Creative thinking: Involves generating alternatives that meet some criteria, such as listing all the possible uses for a brick.

Conventional approach: Conventional approach refers to the traditional way of teaching wherein most of the time lecture method is used.

\section{Design, Subjects, Sample and Sampling Technique of the Study}

As the purpose of this article is to investigate students' perception of cooperative problemsolving in high schools in Awi-zone, Ethiopia, descriptive-survey design was used. Moreover, interview and focus group discussion were utilized.

The participants of this study were grade 11 high school students in Dangila preparatory high school, Awi-zone, Ethiopia. The samples of the study were one hundred five.

Purposive sampling technique was used to select one school from the six preparatory high schools in the zone. This is because this kind of sampling technique can give the opportunity of selection of participants based on previous knowledge and appropriateness for the relevant data. However, for the participants, students, random sampling technique was used, as it can specify equal chances of being selected for each member of a population.

\section{Instruments of Data Collection}

The main tools of data collection for this study were questionnaire, interview, and focus group discussion. Students were interviewed using structured interview protocol. Main interview themes included goals of cooperative problem-solving, student preparation for cooperative 
problem-solving, the cooperative problem-solving process, and assessment of learning. Along with these main topics, the researchers asked the participants whether they had encountered any problems during the process of cooperative problem-solving. Examples of interviewing questions were: 'In your opinion, what are the goals of cooperative problem-solving?', 'How are students prepared for cooperative problem-solving?', 'How do students work together in their groups?', 'How is problems in group learning assessed?', and 'Do you have any problems during the process of cooperative problem-solving? If yes, what are they?' At the end of each interview, the researchers asked the participants whether there were any other problems associated with student cooperative problem-solving, and whether they had any other concerns about cooperative problem-solving practice. Questionnaire items and interview schedules addressed the issues of the extent of students' perception on cooperative problemsolving approach in high schools' teaching learning process. Furthermore, focus group discussion on the situations of the schools unfolded whether or not the attributes of the schools' actual context fit with cooperative problem-solving characteristics reviewed in the literature section.

\section{Methods of Data Analysis}

To analyze students' perception on cooperative problem-solving into the environment of high schools, t-test and narration were used.

\section{Presentation and Analysis of the Findings}

Table 1: Perception of students on cooperative problem-solving \& their performance

\begin{tabular}{|c|c|c|c|c|c|c|}
\hline variables & $\begin{array}{l}\text { Expected } \\
\text { mean }\end{array}$ & $\begin{array}{l}\text { Observed } \\
\text { mean }\end{array}$ & t-value & sd & $\mathrm{df}$ & sig \\
\hline $\begin{array}{l}\text { When I have a problem, I first figure } \\
\text { out cooperatively with my friends } \\
\text { exactly what the problem is and } \\
\text { aware its contribution to } \\
\text { mathematics performance }\end{array}$ & 3 & 3.06 & 0.695 & 5.335 & 104 & 0.09 \\
\hline $\begin{array}{l}\text { I try to get all the facts before trying } \\
\text { to solve a problem in a group and its } \\
\text { contribution to mathematics }\end{array}$ & 3 & 3.72 & 1.114 & 2.979 & 104 & 0.03 \\
\hline $\begin{array}{l}\text { When I have a problem, I look at with } \\
\text { my group how to solve a problem } \\
\text { and its impact on mathematics } \\
\text { performance }\end{array}$ & 3 & 2.98 & 0.968 & 3.025 & 104 & 0.07 \\
\hline
\end{tabular}

The results in table 1 portrays that there was no significant difference $(p=0.09)$ between the means of students understanding of all the facts in a group to solve a problem and see its contribution to mathematics performance, expected mean (3) and observed mean (3.06).

However, there was a significant difference $(p=0.03)$ between the means of students' figuring out of mathematics problems in groups before they try to solve and aware its contribution to mathematics performance, expected mean (3) and observed mean (3.72). It also indicates that students should know more on different strategies for solving a nonroutine problem. 
Furthermore, there was no significant difference $(p=0.07)$ between the expected mean $(3)$ and observed mean (2.98) of how to solve a problem and its impact on mathematics performance. This shows that students are not able to design appropriate strategy in solving a given mathematics problem.

The research indicates that students feel more confident and like they understand the concepts covered in class when they work in cooperative learning groups. Of the ten students interviewed, all except two said they felt more confident in their abilities on non-routine mathematics problems when they worked with their cooperative learning team as opposed to working alone. When the researchers asked students which environment, they were more confident in, some of their comments were as follows:

If I make a mistake, my group members will correct me and vice versa. If I did it correctly, they appreciate me. That makes me confident to know that I will always have at least one person in my group helping me.

Working in a group increased my concentration in doing non-routine math problems. In my group, I get more opinions to see if I do something wrong.

Sometimes I don't understand it when I do something wrong. (sketching a function)

When I work on problems that I have not ever met with my groups cooperatively, I have a better chance of getting the questions right since I can ask people and check.

Furthermore, the focus group discussed on the benefits of learning mathematics through problem solving and cooperative learning approaches and their contribution to their performance.

Therefore, the data suggests that students are more confident in their math abilities when working with their learning groups. Still, not all students have a high level of confidence when it comes to mathematics. The research shows that students have a higher confidence level in cooperative problem-solving as compared to working individually.

\section{Discussion of the findings}

Table 1 show that the observed mean (3.72) is above the expected mean (3.0) for figuring out mathematics problem. This value is significant at $\alpha$ value of 0.05 . This indicates that students were able to transform mathematics problems into figures or diagrams instead of other strategies such as patterns and abstract strategies.

However, as Table 1 portrays, the observed mean (3.06) and the expected mean (3.0) for understanding a problem are almost equal. There is no significant difference at $a$ value of 0.05 . This indicates that students are not familiar with the different ways of understanding a problem. Students are hindered in their efforts to solve problems simply because they do not understand it fully, or even in part. Obviously if you do not understand a problem, you will not be able to solve it. So, it is important to understand what the problem is asking. This requires that you read slowly the problem and carefully understand the information given in the problem. In some cases, drawing a picture or a diagram can help you understand the problem.

Similarly, Table 1 indicates that the observed mean (2.98) and the expected mean (3.0) for devising different plans is not significant at a value of 0.05 . This explains that students are not able to design appropriate strategy in solving a given mathematics problem. This goes with 
the result above which discloses that there is no significant difference between the means of students understanding of all the facts to solve a problem in a group.

The interview and the focus group discussion disclose that cooperative problem solving has contributed a lot in students' mathematics learning. Students began to demonstrate changes in their perception of what they have gained from cooperative problem-solving learning activities. Students prefer to be engaged in non-routine problems in groups as it contributes to their achievement. Both the interview and the focus group discussion revealed that cooperative problem-solving learning has enhanced social skills growth, critical thinking skills, consequently, their mathematics performance.

\section{Conclusions}

This study disclosed that Cooperative Problem-solving Learning is beneficial for the students, particularly for their individual participation, team activity and development of expected skills. In conclusion, after experiencing six weeks of learning in high school mathematics topics, students began to demonstrate changes in their perception of what they have gained from cooperative problem-solving learning activities. Students like to be engaged in non-routine problems in groups. Meanwhile, the study shows that students become more mature in decision making and give full commitment to the class attendance. At the end, the finding of this study shows that Cooperative Problem-solving Learning experiences contribute to social skills growth, critical thinking skills, where positive interpersonal and social relationships became noticeable and more achievement. This is in line with the improvement in students' behavior and their interpersonal relationships. This finding agrees with Gillies (2004) that cooperative learning promotes students' engagement with each other, helping each other's learning and developing social behaviors that encourage groups' active participation. Moreover, the result agrees with Nebesniak (2007) that the transfer of cooperative learning skills is directly related to the exposure of problem-solving situations. Teachers in high school have low professed beliefs of implementation of problem-solving teaching method and this was proved to be true through observation (Bishaw, 2010). On the other hand, there are opportunities for teachers in Amhara Universities to implement problem solving approach (Mengistie, 2015). However, the benefits of cooperative problem-solving learning are not easily realized. It makes significant troubles to the teachers, non-adaptive teams and student resistance or bitterness to group work if it is not appropriately carried out. This paper shared some views and perceptions of high school students who had took part in cooperative problem-solving learning throughout the six weeks during their learning process. All the views and comments are very crucial in order to amend the execution of cooperative problemsolving learning with these students because through this technique the mathematics teacher can importantly assist and prepare the students for their professional career.

\section{REFERENCE}

Ali, R., Hukamdad, D., Akhter, A., \& Khan, A. (2010). Effect of Using Problem Solving Method in Teaching, Mathematics on the Achievement of Mathematics Students, Asian Social Science, 6(2). https://doi.org/10.5539/ass.v6n2p67.

Amhara Education Bureau (2016). Annual report performance of Amhara state teaching learning. 
Artut, P.D. (2016). Effect of cooperative learning method on prospective teachers' nonroutine problem-solving skills and their views about the method. US-China Educ. Review A, 6, 4, 244-254.

Balacheff, N. (1990). Mathematics teaching and mathematics teachers. A Meta-Case Study. For the Learning of Mathematics 12, 3 (November 1992) FLM Publishing Association, White Rock, British Columbia, Canada.

Behlol, M. (2018). Effectiveness of Problem Solving Method in Teaching Mathematics at Elementary Level, Bulletin of Education and Research April 2018, Vol. 40, No. 1 pp. 231 244 .

Bishaw, A. (2010). Teachers' Beliefs and Actual Practice of Problem Solving Approach in Teaching Mathematics (With Particular Reference to Grades 9 and 10 in West Gojjam). Ethiopian Journal of Education and Sciences, 6(1). https://doi.org/10.4314/ejesc.v6i1.65382, 86.

Carpenter, T. P. (1990). The Development of Fifth-Grade Children's Problem-Posing Abilities. Educational Studies in Mathematics, 1997, 34(3), Page 183 Lyn D. English Kluwer Academic Publishers. Printed in the Netherlands.

Cavanagh, M. (2011). Students' experiences of active engagement through cooperative learning activities in lectures, Active Learning in Higher Education, 12(1), 23-33.

Chan, D. (2001). Learning Styles of Gifted and Non-gifted Secondary Students in Hong-Kong. Gifted Children Quarterly, 45(1), 35-44.

Chan, L. L., \& Idris, N. (2017). Cooperative learning in mathematics education, International Journal of Academic Research in Business and Social Sciences, 7(3), 539-553.

Cobb, P., Wood, T., and Yackel, E.(1991). 'Learning through problem solving: A constructivist approach to second grade mathematics', in E.von Glasersfeld (ed.), Radical Constructivism in Mathematics Education, Kluwer, Dordrecht, Netherlands, 157-176.

Davidson, N. (1990). Small-Group Cooperative Learning in Mathematics. In: Cooney, T.J. \& Hirsch, C.R. (Eds.). Teaching and Learning Mathematics in the 1990's, 1990 Yearbook. Reston, Va: NCTM. pp. 52-61.

Driver, R., Asoko, H., Leach, J., Mortimer, E. \& Scott, P. (1994). Constructivist teaching in Primary science, Educational Researcher, 23 (7), 5-12.

Duncker, K. (1945). Introducing effective problem-solving culture in higher education. Journal of Education and Practice www.iiste.org ISSN 2222-1735 (Paper) ISSN 2222-288X (Online) Vol.5, No.25, 2014, 202-209.

Ethiopian national examination agency (NEAEA, 1996-2004). Report on grade 8 students' national exam result.

Evan, R. \& Lappin, G. (1994). 'Constructing meaningful understanding of mathematics content', in Aichele, D. \& A. Coxford (Eds.) Professional Development for Teachers of Mathematics, pp. 128-143. Reston, Virginia: NCTM.

Gilbert-Macmillan, K. M. (1983). Mathematical problem solving in cooperative small groups and whole class instruction, Dissertation Abstracts International, 2700, 4409A.

Gillies, R. (2004). The effects of cooperative learning on junior high school students during small group learning, Learning and Instruction 14(2), 197-213. https://www.researchgate.net/deref/http\%3A\%2F\%2Fdx.doi.org\%2F10.1016\%2FSo9594752(03)00068-9.

Hernandez Garduno, E. L. (1997). "Effects of teaching problem-solving through cooperative learning methods on student mathematics achievement, attitudes toward mathematics, mathematics self-efficacy, and metacognition" (1997). Doctoral Dissertations. AAl9806174.https://opencommons.uconn.edu/dissertations/AAl9806174. 
Johnson, D. W., \& Johnson, R.T. (1989). Cooperation and competition: Theory and research. Edina, MN: Interaction Book Company.

Kamii, C. (1990). Research into practice. Constructivist learning and teaching. Institute of education science, Arithmetic Teacher, 38(1), 34-35.

Leighton, M. S. , Slavin, R. E. , \& Davidson, N. (1989). Achievement effects of individual, small group, and cooperative learning strategies on math problem solving (Report No. 40). Baltimore: Center for Research on Elementary and Middle Schools. (ERIC Document Reproduction Service No. ED 332 862).

Mayer, Richard E. \& Wittrock, Merlin C. (2006). Problem Solving. In Alexander, Patricia A. \& Winne, Philip H. (Ed.): Handbook of Educational Psychology. Routledge, 287.

Mengistie, S. (2015). The Effect of Some Constraints on Mathematics Practices: Universities in Amhara. DOI: http://dx.doi.org/10.4314/star.v4i4. ISSN: 2226-7522 (Print) and 2305-3372 (online) Science, Technology and Arts Research Journal Sci. Technol. Arts Res. J., 4(4), 174-181

Nebesniak, A. (2007). Using Cooperative Learning to Promote a Problem-Solving Classroom, Math in the Middle Institute Partnership Action Research Project Report.

National Council of Teachers of Mathematics (1989). Curriculum and Evaluation Standards for School Mathematics. Reston, VA: Author.

Patrick, A. \& Ochuko, E. (2010). Effects of Cooperative Learning Strategy on Junior Seconda School Students Achievement in Integrated Science. Electronic Journal of Science Education, 14(1), 1-14.

Pervin, K. (2010). Effect Of The Problem-Solving Approach On Academic Achievement Of Students In Mathematics At The Secondary Level, Contemporary Issues In Education Research, 3(3), 9-12.

Peterson, P. L. \& Fennema, E. (1985). Effective teaching, student engagement in classroom activities, and sex-related differences in learning mathematics. American Educational Research Journal, 22, 309-335.

Piaget, J. (1947). The Psychology of Intelligence. Abingdon: Taylor and Francis.

Polya, G. (1995). How to solve it: A new as part of mathematics method.

Stanford University. Principle Hall of India privet Ltd. New DelhiSchoenfeld, A. H. (1987). What's all the fuss about metacognition? In A. Schoenfeld (Ed.), Cognitive science and mathematics education (pp. 189-215). Hillsdale, NJ: Erlbaum.

Shiferaw, A. (2017). Ethiopian Herald. Ethiopia: Improving Student Achievement in Mathematics and Science Education.

Slavin, R. E. (1987). Cooperative learning and the cooperative school, Educational Leadership. 44(11), 7-13.

Slavin, R. E., Madden, N. A. \& Leavey M. (1984). Effects of cooperative learning and individualized instruction on mainstreamed students, Center for Social Organization of Schools, Exceptional Children, 50(5), 434-443.

Von Glasersfeld, E. (1984), 'An Introduction to Radical Constructivism', The Invented Reality: How do we know what we believe we know? (pp.17-40) Watzlawick, P. (ed.), New York, NY: W.W. Norton \& Company.

Wismath, S. L., \& Orr, D. (2015). Collaborative Learning in Problem Solving: A Case Study in Metacognitive Learning, The Canadian Journal for the Scholarship of Teaching and Learning, 6 (3). http://dx.doi.org/10.5206/cjsotl-rcacea.2015.3.10, 1-17

Yackel, E., Cobb, P., Wood, T., Wheatley, G., \& Merkel, G. (1990). The importance of social interactions in children's construction of mathematical knowledge. In T. Cooney (Ed.),1990 Yearbook of the National Council of Teachers of Mathematics (pp.12-21). Reston, VA: National Council of Teachers of Mathematics. 
Zakaria, E., \& Iksan, Z. (2009). Promoting cooperative learning in science and mathematics education: A Malaysian perspective, Eurasia Journal of Mathematics, Science \& Technology Education, 3(1), 35-39. Retrieved from

http://www.cimm.ucr.ac.cr/ojs/index.php/eudoxus/article/viewArticle/448

\section{Biographical notes:}

Adem Mohammed Ahmed currently is PhD student in Mathematics Education.

Dr. Solomon Melesse Mengistie currently is course chair in curriculum department.

Dr. Tadele Ejigu Wondimu the current position: course chair in the department of mathematics. 